\title{
Nitrogen metabolism in sheep
}

\author{
By G. W. MATHISON and L. P. MILLIGAN \\ Department of Animal Science, The University of Alberta, \\ Edmonton, Alberta, Canada
}

(Received 8 June 1970-Accepted 17 November 1970)

\begin{abstract}
I. ${ }^{15} \mathrm{NH}_{4} \mathrm{Cl}$ was continuously infused for periods of $120-216 \mathrm{~h}$ into the rumens of sheep which were allowed to feed 2 out of every $10 \mathrm{~min}$. These treatments achieved steady metabolic states and allowed the assessment of nitrogen conversions by means of tracer methodology. The sheep were given either a barley diet or one of three hay diets. In two trials, the flow of abomasal material was determined using lignin and polyethylene glycol as markers. The amounts of dry matter (DM), gross energy, total $N$, soluble $N$, microbial $N$ and microbial $D M$ in abomasal digesta, and the concentration of ammonia in the rumen liquor were measured. The concentrations of ${ }^{15} \mathrm{~N}$ in the $\mathrm{N}$ of urine, faeces, rumen and abomasal bacteria and protozoa, rumen and abomasal bacterial and protozoal protein, abomasal particulate matter and in rumen ammonia were determined.

2. Comparisons of the steady-state concentrations of ${ }^{15} \mathrm{~N}$ in the microbes with that in rumen ammonia indicated that from 50 to $65 \%$ of the bacterial $\mathrm{N}$ and from $3 \mathrm{I}$ to $55 \%$ of the protozoal $\mathbf{N}$ were derived from rumen ammonia in vivo.

3. An amount of $\mathrm{N}$ equivalent to $60-92 \%$ of the daily intake was transformed into ammonia $\mathrm{N}$ in the rumen.

4. Some $17-54 \%$ of the ammonia was absorbed from the rumen, but this was not readily converted into urea.

5. Microbial growth in the rumen resulted in the assimilation of $\mathrm{r} \cdot 7^{-2} \cdot 6 \mathrm{~g} \mathrm{~N} / \mathrm{r} 00 \mathrm{~g} \mathrm{DM}$ fermented.

6. The generation-time of bacterial protein in the rumen was calculated from the rate of increase of ${ }^{15} \mathrm{~N}$ concentration in this fraction, and values of 38 and $42 \mathrm{~h}$ were obtained for sheep given barley and hay diets respectively.

7. The combined results allowed quantitative estimates to be made of the complete metabolism of rumen $\mathrm{N}$, and from these the possibility of fixation of $\mathrm{N}$ gas in the rumen was suggested.
\end{abstract}

Ammonia may be produced in the rumen from either protein (Blackburn \& Hobson, 1960), or urea (Huhtanen \& Gall, 1955) which enters in the saliva (Somers, 196r) or by diffusion across the rumen wall (Houpt, 1959), or from non-protein nitrogen sources other than urea (Blackburn, 1965).

The results of numerous experiments have shown that rumen micro-organisms utilize ammonia for cell synthesis (Hungate, I966). Bryant \& Robinson (1962) found that ammonia is a preferred source of $\mathrm{N}$ for a large number of rumen organisms, and that it is essential for growth in some species.

The experiments described in this paper were designed to study in vivo the quantitative importance of rumen ammonia for the synthesis of nitrogenous material in rumen microbial cells, a topic which Hungate ( 1966 ) described as 'one of the most intriguing problems in rumen ecology'. In addition, two experiments were undertaken to determine the quantity of plant and microbial material passing through the abomasum. 
EXPERIMENTAL

Animals and feeding regimen

A Southdown ewe and a Suffolk wether weighing approximately 45 and $55 \mathrm{~kg}$, respectively, and both about 2 years of age, were fitted with ruminal and abomasal fistulas at least 2 months before the first experiment was conducted. For at least 2 weeks before and during each experiment, the animals were provided with food for 2 out of every ro min from a timed, moving belt feeder (Ford, 1969). Water was given by continuous infusion into the rumen. The experimental chamber was maintained at $18-20^{\circ}$, with continuous lighting to help maintain steady environmental conditions. Diets $\mathrm{I}$ and 2 were chopped native grass hays which contained $\mathrm{I} \cdot 4$ and $\mathrm{r} \cdot 6 \mathrm{~g} \mathrm{~N} / 100 \mathrm{~g}$ dry matter (DM) respectively. Other diets given were rolled barley and a chopped brome grass-lucerne hay (high-protein hay) which contained $\mathrm{I} .8$ and $2.5 \mathrm{~g} \mathrm{~N} / 100 \mathrm{~g}$ DM respectively.

\section{Infusion and sampling procedures}

Approximately $40 \mathrm{mg}{ }^{15} \mathrm{~N} / 24 \mathrm{~h}$ in the form of ${ }^{15} \mathrm{NH}_{4} \mathrm{Cl}\left(99\right.$ atoms $\%{ }^{15} \mathrm{~N}$; Bio- $\mathrm{Rad}$ Laboratories, Richmond, California) were continuously infused into the middle of the rumen contents of a sheep together with approximately $8 \mathrm{~g}$ polyethylene glycol (PEG) in a total volume of 21 water. Samples (roO- $50 \mathrm{ml}$ ) of digesta were taken from the rumen and the abomasum at $\mathrm{I} 2 \mathrm{~h}$ intervals, and bacteria, protozoa and rumen ammonia were isolated for ${ }^{15} \mathrm{~N}$ determinations. Samples were obtained from several sites in the rumen by the use of a vacuum pump and a rubber tube, and were mixed to yield composite preparations.

\section{Separation of bacteria and protozoa}

Ruminal or abomasal digesta were strained through six to eight layers of cheesecloth and then a cotton cloth (twenty-seven threads $/ \mathrm{cm}$ ) to remove plant debris. Bacteria and protozoa were then separated from the liquid fraction by differential centrifugation (Blackburn \& Hobson, I960). Abomasal contents were used for the separation of bacterial and protozoal fractions derived from the low-protein diets I and 2 and for the preparation of the bacterial fraction from the sheep given the highprotein hay diet. In the trials entailing measurement of passage of material through the abomasum, rumen contents were used for separation of the protozoa derived from the high-protein hay diet and of the protozoa and bacteria derived from the barley diet. This was done to reduce, as far as possible, interference with the normal flow of digesta through the abomasum. Three comparisons of the content of ${ }^{15} \mathrm{~N}$ in comparable microbial preparations from the abomasum and the rumen showed that the site of sampling did not influence the value obtained.

\section{Estimation of plant material passing the abomasum}

The residues from at least four abomasal samples, obtained by straining the abomasal contents through cheese-cloth and washing with water on the cloth to remove all protozoa and loosely bound bacteria, were analysed for $\mathrm{N}$, lignin and ${ }^{15} \mathrm{~N}$ for the trials in which abomasal flow was measured. It was assumed that all of the excess ${ }^{15} \mathrm{~N}$ 
in the residue was in bacterial cell material. The proportion of the $\mathrm{N}$ in the residue that was bacterial was then estimated as

$$
\frac{\text { Excess }{ }^{15} \mathrm{~N} \text { per unit of } \mathrm{N} \text { in residue }}{\text { Excess }{ }^{15} \mathrm{~N} \text { per unit of } \mathrm{N} \text { in isolated bacteria }} \times 100 \% \text {, }
$$

where the isolated bacterial values refer to those determinations on bacterial samples isolated in the same trial. The remaining portion of the $\mathrm{N}$ in the washed residue was considered to be of plant origin. Similar calculations were used to estimate the bacterial and plant DM in the residue. It was then possible, after measuring the lignin in the residue, to calculate the ratios of plant $\mathrm{N}$ to lignin and plant $\mathrm{DM}$ to lignin in the undigested food material passing through the abomasum.

\section{Estimation of microbial material passing the abomasum}

From eleven to fifteen samples of abomasal contents from each trial were centrifuged at $19000 \mathrm{~g}$ for $20 \mathrm{~min}$ and washed twice with water. The resulting sediments obtained were analysed for lignin, total $\mathrm{N}$ and DM. In the calculations used to estimate total abomasal flow-rates of particulate $\mathrm{N}$ and $\mathrm{DM}$, lignin was treated as an indigestible reference marker (Hogan \& Weston, I967a). Similarly, having determined the ratios of plant $\mathrm{N}$ to lignin and plant DM to lignin (above) of the undigested food material, it was possible to estimate the rate of passage of particulate plant $\mathrm{N}$ and DM through the abomasum by the reference-marker technique. The amounts of microbial particulate $\mathrm{N}$ and $\mathrm{DM}$ were then calculated as the difference between total $\mathrm{N}$ and $\mathrm{DM}$ and plant $\mathrm{N}$ and DM. In several instances throughout the experiment, ${ }^{15} \mathrm{~N}$ was determined in the total abomasal particulate matter to check the validity of the above method of estimating abomasal microbial flow. There was always excellent agreement.

\section{Estimation of soluble $N$ passing the abomasum}

PEG was used as a reference marker to estimate the amount of soluble $\mathrm{N}$ passing the abomasum as well as to check the values based upon lignin determinations. The supernatant liquids from the abomasal contents separated by the above procedure were used for the determination of PEG and soluble N.

\section{Analytical methods}

Ammonia in rumen liquid was prepared for isotopic analysis by distillation from centrifuged rumen fluid, made basic by the addition of an excess of $2 \mathrm{~N}-\mathrm{KOH}$. The total concentration of base in the distillate, which would include methylamine as well as ammonia if methylamine was present in the rumen liquid, was determined by titration and was compared with the concentration of ammonia determined by the method of Fawcett \& Scott (1960), which does not measure aliphatic amines. This comparison showed that over $99 \%$ of the volatile base in the rumen liquor was ammonia.

Microbial protein was isolated for ${ }^{15} \mathrm{~N}$ determinations by the method of Roberts, Abelson, Cowie, Bolton \& Britten (1955). 
${ }^{15} \mathrm{~N}$ was measured on a mass spectrometer (CEC 2I-614 RGA) using gaseous $\mathrm{N}$ prepared for analysis by the procedure of Mulligan \& Workmall (1959). Samples of rumen ammonia and microbial protein were taken before each trial to ascertain if there was any accumulation of ${ }^{15} \mathrm{~N}$ between trials; there was no evidence of any such accumulation. The mean of the pre-trial abundance by our method of determination was 0.3475 atoms $\%{ }^{15} \mathrm{~N}$ with a standard deviation of \pm 0.0023 .

Total $\mathrm{N}$ was determined by the Kjeldahl method, and gross energy by the oxygen bomb calorimeter. Samples were dried to constant weight at $105^{\circ}$ under reduced pressure for DM determinations. PEG was estimated by the method of Smith (1959), with turbidity readings at $525 \mathrm{~nm}$ after $20 \mathrm{~min}$.

Lignin was determined by the $72 \%$ (w/w) $\mathrm{H}_{2} \mathrm{SO}_{4}$ method of Norman \& Jenkins (1934), with a final refluxing period of $3 \mathrm{~h}$. Recovery of lignin in the faeces when the high-protein hay diet was given was only $69 \%$. In agreement with the suggestions of Badawy, Campbell, Cuthbertson, Fell \& Mackie (1958) and of Hogan \& Phillipson (1960), no digestion of lignin took place in the rumen of the sheep as determined by comparing calculated flow-rates based upon lignin passage through the abomasum and the flow-rates of abomasal material estimated with PEG.

\section{RESULTS}

The small differences between the intake of digestible energy by the sheep in the four experiments (Table $\mathbf{r}$ ) make it possible to compare the effect of different dietary $\mathrm{N}$ contents and types of food on the $\mathrm{N}$ metabolism of the sheep.

\section{Microbial utilization of rumen ammonia}

The enrichment of the bacterial, protozoal, urinary and faecal samples with ${ }^{15} \mathrm{~N}$ is shown in Fig. I for each of the four diets. The transfer quotients, obtained by expressing the concentrations of ${ }^{15} \mathrm{~N}$ in these fractions at steady state as a percentage of the rumen ammonia enrichment, indicate the proportion of the $\mathrm{N}$ in the fraction that was derived from rumen ammonia (Table 2). The transfer quotients show that from 50 to $65 \%$ of the bacterial protein $\mathrm{N}$ was derived from rumen ammonia and that the concentration of isotope in the total $\mathrm{N}$ of the bacteria was only slightly higher than the ${ }^{15} \mathrm{~N}$ enrichment of the protein $\mathrm{N}$ fraction. Since the experimental methods were such that only ammonia which equilibrated with extracellular rumen ammonia would be measured as contributing to bacterial $\mathrm{N}$, these transfer quotients represent a minimum range for the utilization of ammonia by the bacteria.

As the concentrations of rumen ammonia increased when the hay rations were given to the sheep, there may have been a decrease in the proportion of ammonia utilized by the bacteria (Fig. 2). However, measurements were made at only three concentrations of rumen ammonia.

$\mathrm{N}$ derived from rumen ammonia formed $3 \mathrm{I}-55 \%$ of the protozoal protein $\mathrm{N}$ and a slightly smaller percentage of total protozoal $\mathrm{N}$ (Table 2). The pathway for this incorporation could have been either direct through the utilization of ammonia $\mathrm{N}$, or indirect through the utilization of bacterial $\mathrm{N}$. The enrichment of the protozoal 


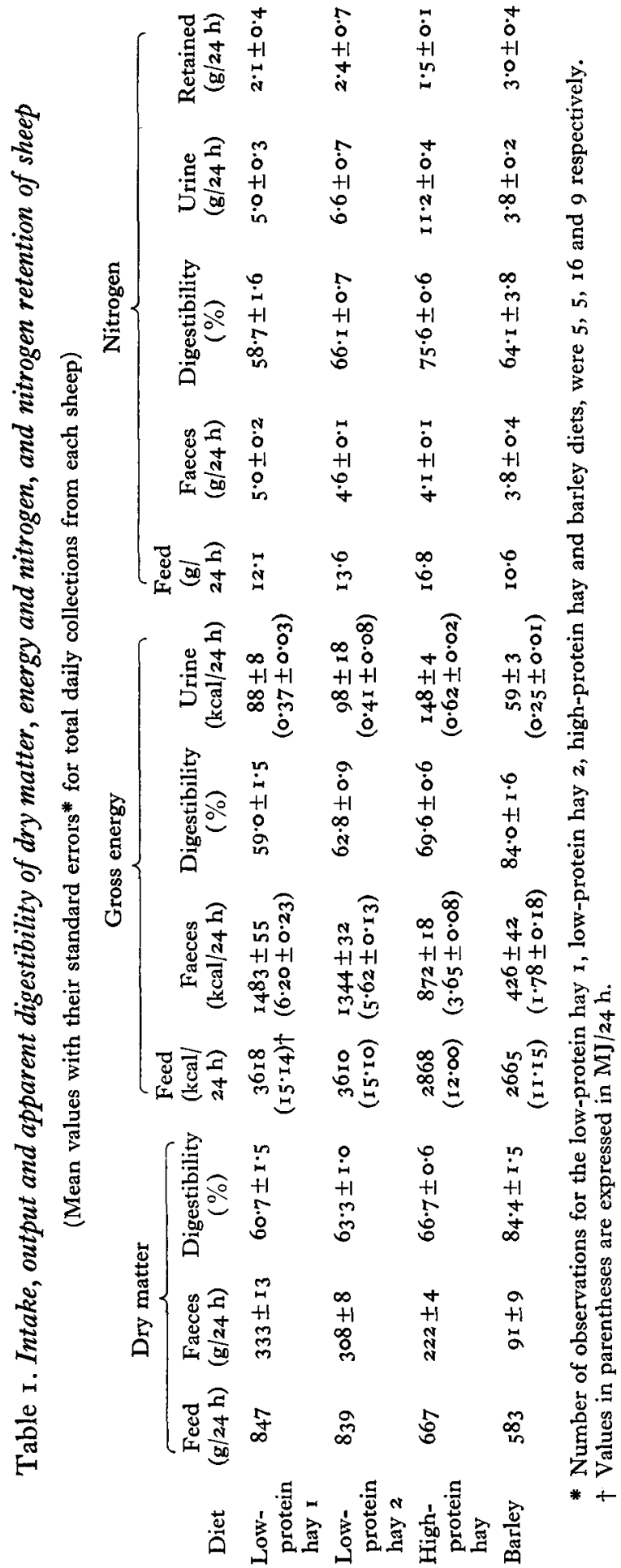


fraction with ${ }^{15} \mathrm{~N}$ was $56-96 \%$ of that of the bacterial fraction. Ulbrich \& Scholz ( $1966 a$ ) obtained a value of $76 \%$ when [ $\left.{ }^{15} \mathrm{~N}\right]$ urea was given to cows and a more complete, but lengthy, method of protozoal separation that may have allowed metabolism during isolation was used.
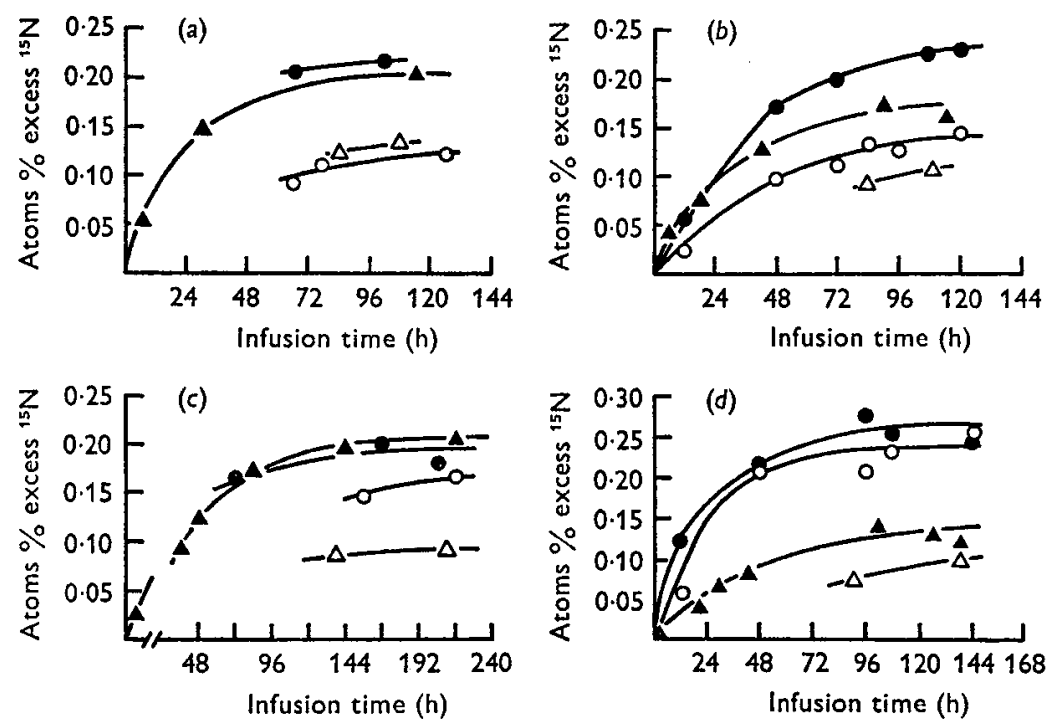

Fig. $x$. Incorporation of nitrogen from intraruminally infused ${ }^{15} \mathrm{NH}_{4} \mathrm{Cl}$ into bacterial protein (O), protozoal protein $(O)$, urinary $N(\Delta)$, and faecal $N(\Delta)$ in samples taken from sheep given (a) low-protein hay I, (b) low-protein hay $2,(c)$ high-protein hay or $(d)$ barley. The break in the time axis of the graph $(c)$ represents an $8 \mathrm{~h}$ pause in infusion.

Table 2. Concentration, in sheep, of ${ }^{15} N$ in microbial $N$ fractions, urinary $N$ and faecal $N$ as $\%$ of the concentration of ${ }^{15} \mathrm{~N}$ in rumen ammonia at steady state

Diet

Low-protein hay I

Low-protein hay 2

High-protein hay

Barley

$\begin{array}{cccccc}\begin{array}{c}\text { Total } \\ \text { bacterial }\end{array} & \begin{array}{c}\text { Bacterial } \\ \text { protein }\end{array} & \begin{array}{c}\text { Total } \\ \text { protozoal }\end{array} & \begin{array}{c}\text { Protozoal } \\ \text { protein }\end{array} & \text { Urinary } & \text { Faecal } \\ - & 55 & - & 31 & 53 & 34 \\ - & 65 & - & 40 & 50 & 31 \\ 53 & 50 & 37 & 40 & 53 & 24 \\ 6 \text { r } & 57 & 53 & 55 & 30 & 23\end{array}$

\section{Turn-over time of bacteria}

The turn-over, or generation, time of the bacteria was calculated by first-order kinetic analysis (Sheppard, 1962) of the rate of enrichment of bacterial $\mathrm{N}$ with ${ }^{15} \mathrm{~N}$ from ammonia (Fig. 3). The turn-over times for bacterial protein $\mathrm{N}$ in the rumen of the sheep given the low-protein hay 2 and barley diets were 42 and $38 \mathrm{~h}$ respectively. Ulbrich \& Scholz (1963) and Ulbrich \& Scholz (1966a) reported turn-over times for bacteria in cattle of $27 \mathrm{~h}$ and $28-29 \mathrm{~h}$. The times required for replacement (turn-over) of the rumen liquid before the trials were calculated from first-order analysis of the rate of disappearance of PEG from the rumen of the sheep given either the highprotein hay or barley diets, and values of 12.4 and $14.8 \mathrm{~h}$, respectively, were obtained 
(Fig. 4). These turn-over times indicate that the bacteria in the rumen move predominately with the solid fraction of the rumen contents, and not with the liquid fraction.

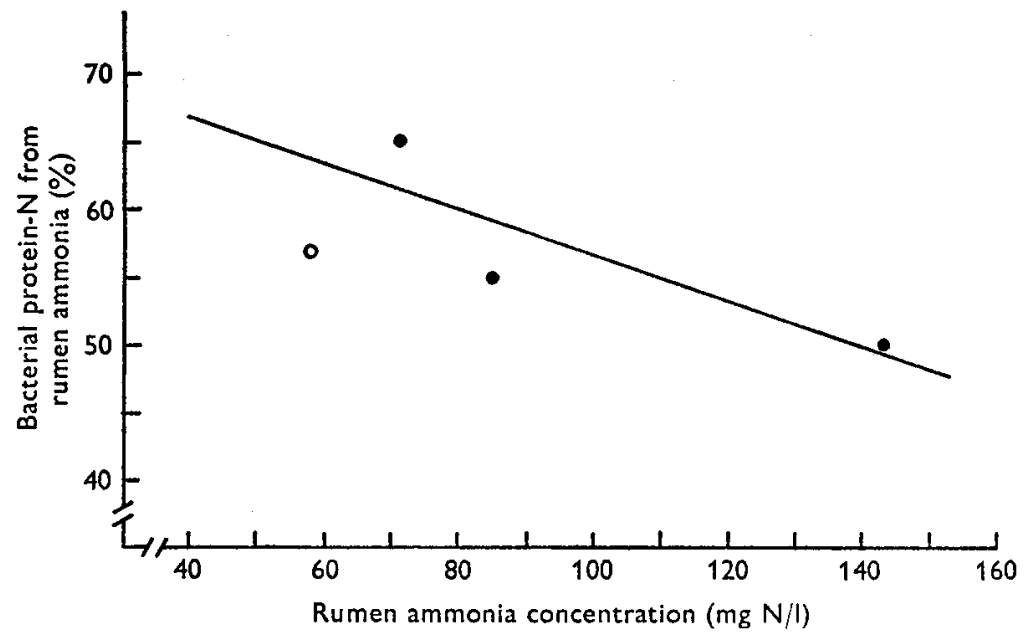

Fig. 2. Relationship of percentage utilization of ammonia nitrogen by bacteria for cell synthesis and rumen ammonia concentration for sheep given hay diets (O). For comparison, the value for the sheep given the barley diet is also shown (O). The regression line is for the results with hay diets.

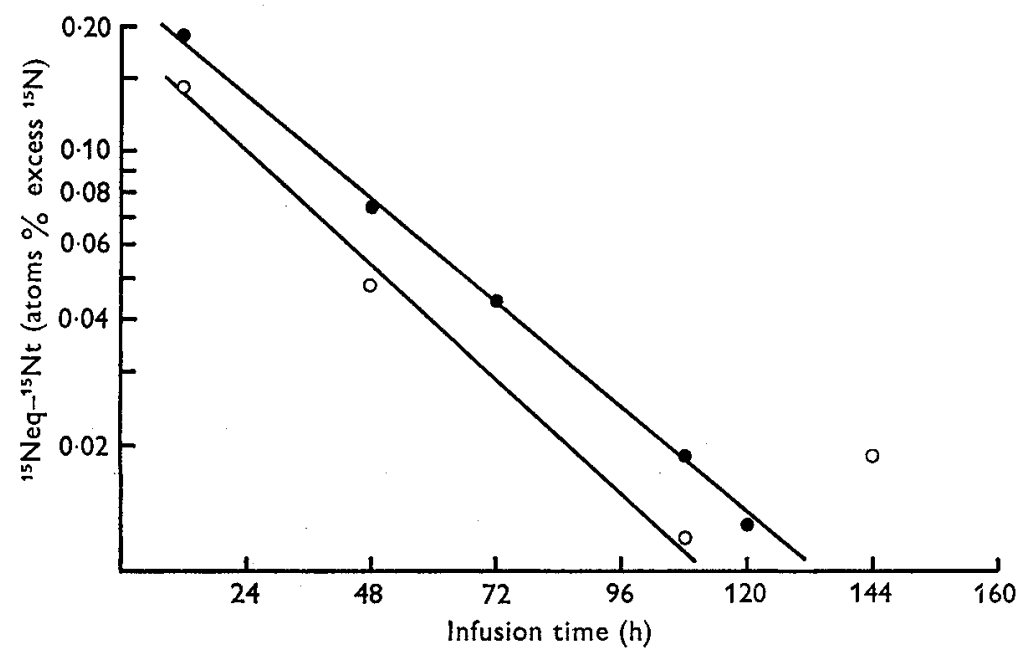

Fig. 3. Rate of replacement of nitrogen in bacterial protein $\mathrm{N}$ with intraruminally infused ${ }^{15} \mathrm{~N}$ from ${ }^{15} \mathrm{NH}_{4} \mathrm{Cl}$ in sheep given a low-protein hay diet $(O)$ or a barley diet $(O) .{ }^{15} \mathrm{Neq}$ refers to the concentration of isotope in the bacteria at steady state and ${ }^{15} \mathrm{Nt}$ refers to the concentration of ${ }^{15} \mathrm{~N}$ at time $\mathrm{t}$.

\section{Microbial growth}

The amount of microbial $\mathrm{N}$ which passed through the abomasum daily was found to be from 7.8 to $9.4 \mathrm{~g}$ and from 9.2 to $12.9 \mathrm{~g}$ in the sheep given the high-protein hay and barley diets respectively (Tables 3 and 4 ). The larger value for each diet was 
calculated on the assumption that the soluble $\mathrm{N}$ passing through the abomasum, after correction for gastric juice $\mathrm{N}$ ( $\mathrm{I} \mathrm{g} \mathrm{N} / 24 \mathrm{~h}$; Weston \& Hogan, I967) and for rumen ammonia, was of microbial origin. Since there is considerable disruption of microbial cells in the abomasum, as evidenced by microscopic observations (Annison \& Lewis, 1959), and since most of the plant $\mathrm{N}$ is digested in the rumen (Weller, Pilgrim \& Gray, 1962), the higher value is probably closer to the actual growth which took place in the rumen.

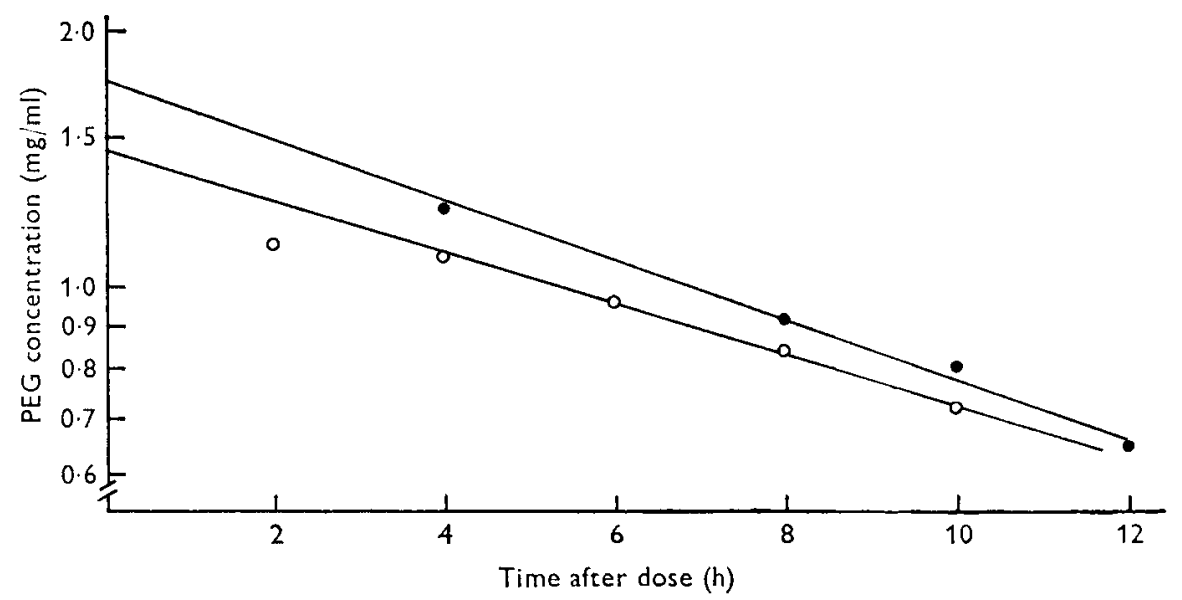

Fig. 4. Rate of disappearance of polyethylene glycol (PEG) from the rumen of sheep given high-protein hay $(\mathcal{O})$ or barley $(\bigcirc)$. The initial point on the barley line was considered to represent inadequate mixing.

The barley diet supported from $\mathrm{I} \cdot \mathrm{I}$ to $\mathrm{I} \cdot 3$ times more synthesis of microbial cellular $\mathrm{N}$ than the hay diet as measured by $\mathrm{g} \mathrm{N}$ assimilated/roo $\mathrm{g}$ DM fermented (Table 4). Yields of microbial $\mathrm{N}$ per unit of food energy fermented in the rumen from the two substrates were, however, similar.

\section{Production of rumen ammonia}

Values for the metabolism of rumen ammonia are given in Table 5. The quantity of $\mathrm{N}$ converted into rumen ammonia was estimated from the extent of dilution of the infused isotope in rumen ammonia upon achievement of steady-state enrichment, as described by Steele, Wall, De Bodo \& Altzuler (1956). The calculation used was

$\mathrm{N}$ converted into rumen ammonia $(\mathrm{g} \mathrm{N} / 24 \mathrm{~h})=$ ${ }^{15} \mathrm{~N}$ infused (atoms/24 h) $\times 14 \mathrm{~g} \mathrm{~N} /$ atom steady-state enrichment of rumen ammonia (atoms \% excess ${ }^{15} \bar{N}$ ).

The $\mathrm{N}$ converted into ammonia was equivalent to $60-92 \%$ of the daily $\mathrm{N}$ intake. Increases in the concentration of rumen ammonia in the sheep given the hay diets were accompanied by decreases in the conversion of $\mathrm{N}$ into ammonia when this conversion was expressed as a percentage of total $\mathrm{N}$ intake (Fig. 5). This relationship was described by the equation $Y=123-0.44 X$, where $Y=\mathrm{N}$ converted into rumen 
Vol. 25

Nitrogen metabolism in sheep

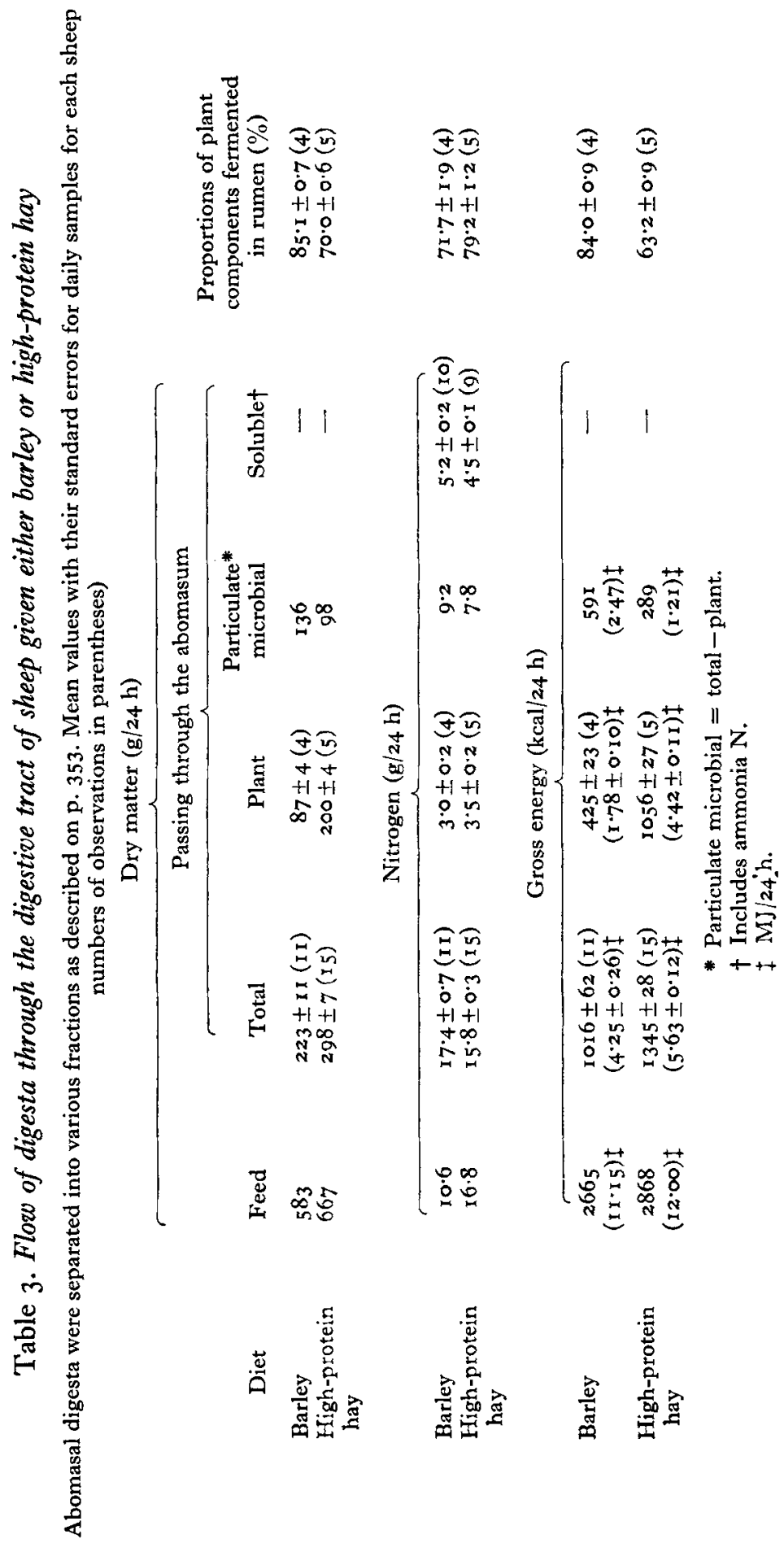


ammonia, expressed as a percentage of $\mathrm{N}$ intake, and $X=$ concentration of rumen ammonia (mg N/l).

Pilgrim, Gray \& Belling ( 1969 ) found that production of rumen ammonia was equivalent to $25 \%$ of the daily $\mathrm{N}$ intake in sheep given a hay-chaff of very high protein

\section{Table 4. Microbial growth in the rumen of sheep given either barley or high-protein hay}

\section{Measure of growth}

Total $\mathrm{N}$ incorporated $(\mathrm{g} / \mathbf{2 4} \mathrm{h})$

$\mathrm{N}$ assimilated/100 g DM fermented $(\mathrm{g})$

$\mathrm{N}$ assimilated/rooo kcal energy fermented $(\mathrm{g})$

Yield of cell wt/roo g DM fermented, assuming $10.5 \% \mathrm{~N}$ in cells $(\mathrm{g})$

\begin{tabular}{|c|c|c|c|}
\hline \multicolumn{2}{|c|}{ Barley } & \multicolumn{2}{|c|}{ High-protein hay } \\
\hline$a^{*}$ & b† & $a^{*}$ & $\mathrm{~b} \dagger$ \\
\hline $9 \cdot 2$ & $12 \cdot 9$ & $7 \cdot 8$ & 9.4 \\
\hline $1 \cdot 9$ & $2 \cdot 6$ & $I \cdot 7$ & $2 \cdot 0$ \\
\hline $\begin{array}{r}4 \cdot 1 \\
18 \cdot 1\end{array}$ & $\begin{array}{r}5.8 \\
24.8\end{array}$ & $\begin{array}{r}4.3 \\
16.2\end{array}$ & $\begin{array}{r}5.2 \\
19.0\end{array}$ \\
\hline
\end{tabular}

* Calculated on the assumption that the soluble, non-ammonia $\mathrm{N}$ passing through the abomasum was not of microbial origin.

+ Calculated on the assumption that the soluble, non-ammonia $N$ passing through the abomasum, corrected for digestive secretions as described on p. 358 , was of microbial origin.

\section{Table 5. Metabolism of rumen ammonia in sheep given either barley or hay}

(Mean values; their standard errors given where appropriate; numbers of observations in parentheses)

\begin{tabular}{|c|c|c|c|c|}
\hline & $\begin{array}{l}\text { Low-protein } \\
\text { hay } \mathbf{I}\end{array}$ & $\begin{array}{l}\text { Low-protein } \\
\text { hay } 2\end{array}$ & $\begin{array}{l}\text { High-protein } \\
\text { hay }\end{array}$ & Barley \\
\hline $\begin{array}{l}\text { Ammonia concentration } \\
\text { (mg N/l) } \\
\text { Quantity of ammonia in }\end{array}$ & $85 \pm 4(6)$ & $71 \pm 5(6)$ & $143 \pm 8(7)$ & $58 \pm 5(6)$ \\
\hline rumen $(\mathrm{mg} \mathrm{N}) *$ & - & 一 & $8 I_{5}$ & 406 \\
\hline${ }^{15} \mathrm{~N}$ infused $\left(\mathrm{mg}{ }^{15} \mathrm{~N} / 24 \mathrm{~h}\right)$ & $43 \cdot 27$ & $47 \cdot 5 \circ$ & $42 \cdot 60$ & $4 I \cdot 84$ \\
\hline $\begin{array}{l}\text { Atoms } \% \text { excess }{ }^{15} \mathrm{~N} \text { in } \\
\text { rumen ammonia } \\
\text { Conversion of } \mathrm{N} \text { into } \\
\text { rumen ammonia }\end{array}$ & $0.391 \pm 0.007(3)$ & $0.356 \pm 0.012(4)$ & $0.394 \pm 0.018(5)$ & $0.460 \pm 0.033(5)$ \\
\hline $\begin{array}{l}(\mathrm{g} \mathrm{N} / 24 \mathrm{~h}) \dagger \\
\text { Turn-over time of ammon } \\
\text { based upon conversion of }\end{array}$ & $10 \cdot 34$ & $12 \cdot 46$ & $10 \cdot 10$ & $8 \cdot 48$ \\
\hline $\begin{array}{l}\mathrm{N} \text { into ammonia (min) } \downarrow \\
\text { Urea recycled to rumen }\end{array}$ & - & 一 & I 16 & 69 \\
\hline $\begin{array}{l}(\mathrm{g} \mathrm{N} / 24 \mathrm{~h}) \\
\text { Possible conversion of } \mathrm{N} \text { in }\end{array}$ & - & - & $6 \cdot 0$ & 30 \\
\hline $\begin{array}{l}\text { ammonia ( }(\mathrm{g} \mathrm{N} / 24 \mathrm{~h}) \S \\
\text { Possible turn-over time of }\end{array}$ & 一 & - & $13 \cdot 28$ & $9 \cdot 38$ \\
\hline ammonia (min) $\uparrow$ & 一 & - & 88 & 62 \\
\hline \multicolumn{5}{|c|}{ 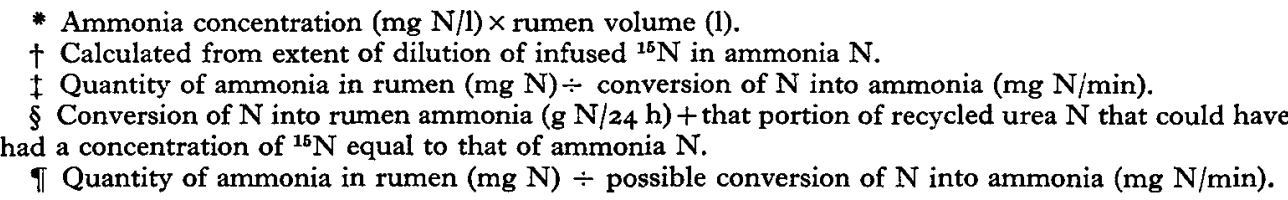 } \\
\hline
\end{tabular}

content and with rumen ammonia concentrations of $20 \mathrm{r} \mathrm{mg} \mathrm{N} / \mathrm{l}$. Our prediction of $35 \%$, calculated by using the concentration of ammonia in the rumen reported by Pilgrim et al. (1969) in the above equation, is similar to the value determined by these investigators.

It is possible that more $\mathrm{N}$ was converted into ammonia than the quantity measured. 
This greater quantity, referred to as the possible conversion of $\mathrm{N}$ into ammonia in Table 5 and used in Table 6 , would be dependent upon the amount of urea that was recycled to the rumen from the blood and the enrichment of the recycled urea. The value of $3 \mathrm{~g} \mathrm{~N}$ for the amount recycled as urea in the sheep given the barley diet was estimated from an equation derived by Ford (1969) for sheep under the same management and feeding conditions as used in this study. This equation relates urea recycling

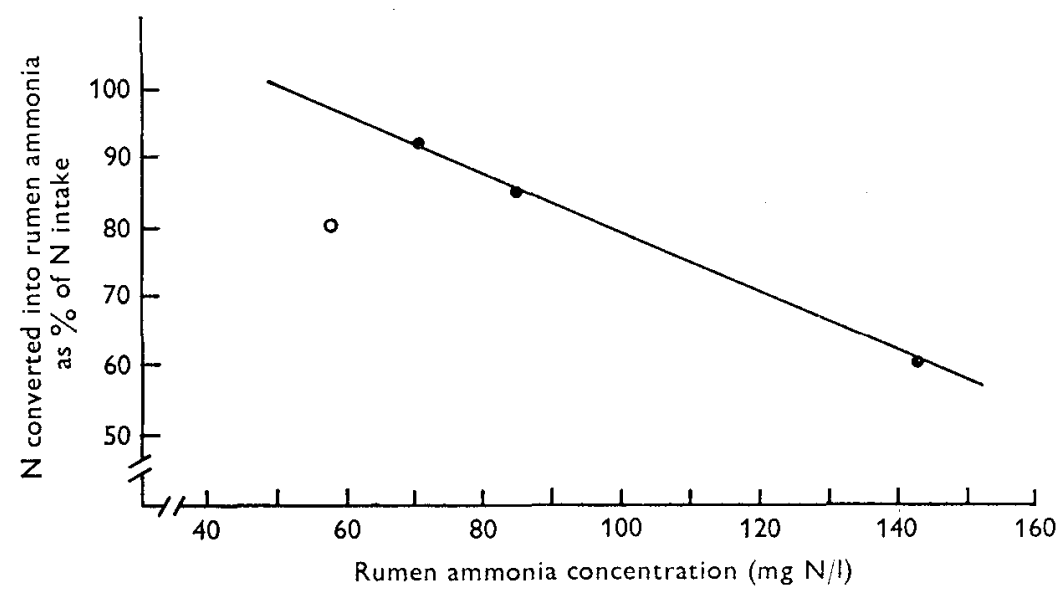

Fig. 5. Relationship of the quantity of nitrogen converted into rumen ammonia, expressed as a percentage of daily $N$ intake, and rumen ammonia concentration for sheep given hay diets $(\bullet)$. The result for the barley diet is also shown $(O)$ for comparison.

to plasma urea concentration. The urea recycled was predicted for a plasma urea concentration of $15 \mathrm{mg}$ urea/roo ml, which was the concentration measured in this

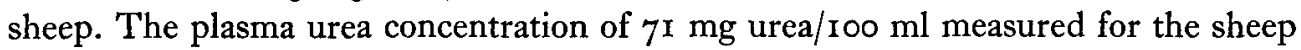
given the high-protein hay diet was sufficiently high to presume that there was maximal recycling of urea, which would be $6 \mathrm{~g} \mathrm{~N} / 24 \mathrm{~h}$ in sheep (Ford, I969; Cocimano \& Leng, 1967; Weston \& Hogan, 1967). The ${ }^{15} \mathrm{~N}$ enrichment of the recycled urea $\mathrm{N}$ was assumed to be similar to the enrichment of the total urinary $\mathrm{N}$, since Ulbrich \& Scholz $(\mathrm{r} 966 b)$ reported that urinary urea $\mathrm{N}$ was only slightly more enriched than total urinary $\mathrm{N}$ after oral intake of $\left[{ }^{15} \mathrm{~N}\right]$ urea by cows.

\section{Absorption from the rumen}

Quantitative estimates of metabolism of $\mathrm{N}$ in the rumen are given in Table 6. Microbial estimates include that portion of the soluble fraction which was assumed to have arisen from microbial disintegration in the abomasum, which, as indicated previously, is the soluble $\mathrm{N}$ passing through the abomasum corrected for the $\mathrm{N}$ in ammonia and digestive secretions.

A considerable amount of ammonia $\mathrm{N}$ was absorbed from the rumen, which is in agreement with reports of other workers (Gray, Pilgrim \& Weller, 1958). Pilgrim et al. (1969) found that from 3 to $4.6 \mathrm{~g}$ ammonia $\mathrm{N} / 24 \mathrm{~h}$ were absorbed from the rumen of sheep given a high-protein hay.

It is suggested that $0.8 \mathrm{~g} \mathrm{~N}$ was absorbed from the rumen in the form of amino acids 
or other non-ammonia $\mathrm{N}$ on the high-protein hay ration; such absorption would account for the difference between the flow of $\mathrm{N}$ into and out of the rumen (Table 6). The absorption of amino acids from the rumen has been demonstrated previously by Cook, Brown \& Davis (1965).

Table 6. Quantitative estimates of the metabolism of nitrogen in the rumen of sheep given either barley or high-protein hay

\begin{tabular}{|c|c|c|}
\hline \multirow{2}{*}{\multicolumn{3}{|c|}{ Inflow of rumen $N(g / 24 h)$ : }} \\
\hline & & \\
\hline Urea $\mathrm{N}$ recycled & 6.0 & $3 \cdot 0$ \\
\hline Unaccounted for $N^{*}$ & - & $4 \% 4$ \\
\hline Total inflow of rumen $\mathrm{N}(\mathrm{g} / 24 \mathrm{~h})$ & $22 \cdot 8$ & $18 \cdot 0$ \\
\hline \multicolumn{3}{|l|}{ Outflow of rumen $\mathrm{N}(\mathrm{g} / 24 \mathrm{~h})$ : } \\
\hline Microbial $\mathbf{N}$ from ammonia $\nmid$ & 4.2 & $7 \cdot 3$ \\
\hline Rumen ammonia passing abomasum & I.9 & 0.5 \\
\hline Ammonia absorbed from rument & $7 \cdot 2$ & $I \cdot 6$ \\
\hline Undigested food $\mathrm{N}$ & $3 \cdot 5$ & 3.0 \\
\hline Microbial $\mathrm{N}$ direct from food§ & $5 \cdot 2$ & $5 \cdot 6$ \\
\hline Absorbed amino acid $N^{*}$ & 0.8 & - \\
\hline Total outflow of rumen $\mathrm{N}(\mathrm{g} / 24 \mathrm{~h})$ & $22 \cdot 8$ & $18 \cdot 0$ \\
\hline
\end{tabular}

* Difference between total $\mathrm{N}$ inflow and total $\mathrm{N}$ outflow.

$\uparrow$ Proportion of microbial $N$ from ammonia (average of bacterial $\mathrm{N}$ and protozoal $\mathrm{N}, \mathrm{Table} 2$ ) $\times$ maximum microbial incorporation of $\mathrm{N}$ (Table 4).

$\ddagger$ Possible conversion of $\mathrm{N}$ into ammonia (Table 5 ) - (microbial $\mathrm{N}$ from ammonia + rumen ammonia passing abomasum).

$\S$ Proportion of microbial $\mathrm{N}$ not from ammonia (average of bacterial $\mathrm{N}$ and protozoal $\mathrm{N}$, Table 2) $\times$ maximum microbial incorporation of $\mathrm{N}$ (Table 4).

\section{DISCUSSION}

\section{Microbial utilization of rumen ammonia}

The large percentage utilization of ammonia for bacterial synthesis in the present experiments (Table 2) agrees with in vivo results reported previously. Portugal (1963), using carbon-labelled amino acids found that only about 10\% of the carbon of amino acids is incorporated into microbial protein in the rumen, whereas Weller et al. (I962) concluded that up to $80 \%$ of the dietary plant $\mathrm{N}$ is incorporated into microbial cells. These findings indicate that the carbon and $\mathrm{N}$ of dietary protein are separated during metabolism in the rumen before incorporation of the $\mathrm{N}$ into microbial cells. Bryant $\&$ Robinson ( 1962 ) have shown both a requirement and a preference by certain rumen organisms for ammonia compared with amino acids. Hobson, McDougall \& Summers (I968) found that one rumen isolate formed $93 \%$ of its cellular $\mathrm{N}$ from ammonia. Clearly, rumen ammonia is a very important source of rumen microbial $\mathrm{N}$.

Investigations using heterotrophic bacteria have suggested that there is a tendency towards increased incorporation of amino acids and peptides when these are available (Roberts et al. 1955; Warner, 1956). Since there is a positive correlation between the concentrations of non-protein, non-ammonia $\mathrm{N}$ and ammonia $\mathrm{N}$ in the rumen (Blackburn \& Hobson, I960), when concentrations of ammonia increase there are likely to be enhanced amounts of amino acids and peptides available to the rumen 
population. This would support the suggestion, from the admittedly small number of results in our experiments, that percentage utilization of ammonia by bacteria decreased as concentrations of rumen ammonia increased when the hay diets were given (Fig. 2). This also explains the negative correlation between the $\mathrm{N}$ converted into rumen ammonia as a percentage of $\mathrm{N}$ intake and the rumen ammonia concentration (Fig. 5).

The concentration of isotope in the total $\mathrm{N}$ content of the bacteria was only slightly higher than that in the protein $\mathrm{N}$ fraction (Table 2). This would indicate that the incorporated non-protein $\mathrm{N}$ is a precursor of protein $\mathrm{N}$ in bacterial cells. It is also possible that the proportion of the $\mathrm{N}$ in nucleic acids that is derived from ammonia is greater than that in protein. The large concentrations of nucleic acids in rumen microorganisms (Smith, McAllan \& Hill, I968) indicate substantial synthesis of these acids in the rumen.

\section{Microbial growth}

The microbial yields of $\mathrm{I} \cdot 7-2 \cdot 6 \mathrm{~g} \mathrm{~N}$ assimilated/100 $\mathrm{g}$ DM fermented in the rumen obtained in these experiments are considerably higher than the estimate of $\mathrm{I} \cdot \mathrm{I} g \mathrm{~N}$ incorporated/100 g DM fermented derived by Hungate (1966), who used both direct and indirect methods of calculating microbial yields. Microbial yields in the range of those obtained in this experiment ( $2 \mathrm{~g} \mathrm{~N}$ assimilated/roo g substrate fermented) have, however, been obtained by various workers under in vitro conditions of continuous culture (Hungate, I963; Hobson, 1965; Hobson \& Summers, 1967). Conrad \& Hibbs (1968), from in vivo studies in which methionine synthesized in the rumen was used as an indicator of the total cell $\mathrm{N}$ synthesized, estimated that $\mathrm{I} \cdot 63 \mathrm{~g} \mathrm{~N} / \mathrm{roo} \mathrm{g}$ digestible DM were assimilated in the cow's rumen.

The yield of microbial cellular $\mathrm{N}$ in the rumen can also be estimated from the flow of digesta through the abomasum and the proximal duodenum. This flow was measured by Meyer, Gaskill, Stoewsand \& Weir (1959), Hogan \& Phillipson (1960), Harris $\&$ Phillipson (1962), Hogan \& Weston (1967a, $b, 1969)$, Weston \& Hogan (1968), and Topps, Kay \& Goodall ( 1968 ), and their results were used to relate the net loss of $\mathrm{N}$ in the rumen to the percentage $\mathrm{N}$ in the food. The equation obtained was: $Y=4.3 \mathrm{I} X-8.6 \mathrm{I}$, where $Y=$ difference between the intake of $\mathrm{N}$ in the food $(\mathrm{g} / 24 \mathrm{~h})$ and the passage of $\mathrm{N}$ through the abomasum or duodenum $(\mathrm{g} / 24 \mathrm{~h})$ and $X=$ percentage of $\mathrm{N}$ in the DM of the food. The standard error of the estimate was $2 \cdot 4 \circ \mathrm{g} \mathrm{N}$ and the correlation coefficient was 0.886 . In deriving this equation, it was assumed that $\mathrm{I} g$ gastric juice $\mathrm{N}$ was added to the abomasum daily (Weston \& Hogan, 1967). Then, $Y=0$ when the diet contains $2 \% \mathrm{~N}$. It may be assumed that any large excess of rumen ammonia passing from the rumen is absorbed in the omasum, as indicated by results of Hogan $\&$ Weston $(1967 a)$, and that the extents of digestoin of $\mathrm{DM}$ and of $\mathrm{N}$ in the rumen are similar. This equation would then suggest that there was assimilation of $\mathrm{N}$ by the microbes to the extent of $2 \%$ of the fermentable substrate in the rumen; that is, for every $100 \mathrm{~g}$ dietary $\mathrm{DM}$ fermented in the rumen, $2 \mathrm{~g}$ dietary $\mathrm{N}$ have been digested and $2 \mathrm{~g} \mathrm{~N}$ pass into the abomasum in cell material.

Hobson (1965) and Hobson \& Summers (1967) have shown that the yield of microbial cellular material in anaerobic fermentation is directly proportional to the growth rate of the microbes. The apparently large yields of $I \cdot 7-2 \cdot 6 \mathrm{~g} \mathrm{~N}$ assimilated into cell 
material by the micro-organisms per $100 \mathrm{~g} \mathrm{DM}$ fermented appear to be inconsistent with the slow turn-over time of $40 \mathrm{~h}$ found for the bacterial cells. There are many instances of changes in the enzymic complement of bacteria in response to different conditions. It is possible that micro-organisms in the rumen adapt to conditions in which substrate is continuously available, and the removal of end-products is rapid, by reducing endogenous metabolism and by using substrates more efficiently.

\section{Utilization of absorbed rumen ammonia}

There was considerable absorption of ammonia from the rumen (Table 6). Ammonia is converted into urea in the liver (Lewis, Hill \& Annison, 1957); thus, if the ammonia that left the rumen through the rumen wall was transported as such to the liver and mixed with the ammonia serving for urea synthesis in the present experiments, it should have contributed to the ${ }^{15} \mathrm{~N}$ enrichment of urea within the relatively short time that was required for the blood to flow from the rumen to the liver. Ford (1969) found that, after intravenous injections of $\left[{ }^{14} \mathrm{C}\right]$ urea in sheep, $85 \%$ of the ${ }^{14} \mathrm{C}$ that was excreted in the urine appeared within $12 \mathrm{~h}$. Fig. I shows that the increase in enrichment of urinary $\mathrm{N}$ was not rapid during infusion of ${ }^{15} \mathrm{NH}_{4} \mathrm{Cl}$, even though the enrichment of rumen ammonia $\mathrm{N}$ reached a steady state within $\mathrm{I} 2 \mathrm{~h}$ when the sheep was given the barley ration. Instead, the increase in enrichment of urinary $\mathrm{N}$ was continuous and similar to the increase of ${ }^{15} \mathrm{~N}$ in the microbial $\mathrm{N}$. Thus, absorbed ammonia may not have been converted directly into urea in substantial amounts in our sheep. Studies using ${ }^{15} \mathrm{~N}$-labelled ammonium sources in cows (Land \& Virtanen, r959; Faust, Gürtler, Hübner, Hübner, Mielke, Rommel, Ulbrich \& Wetzel, 1963; Faust, Mielke, Richter \& Gürtler, I966) have shown a rapid incorporation of ammonia N into both total $\mathrm{N}$ and protein $\mathrm{N}$ in milk, which also indicates that absorbed ammonia $\mathrm{N}$ may be utilized by a pathway other than the direct conversion into urea.

Glutamate dehydrogenase has been found in rumen epithelium, and the formation of glutamate from 2-oxoglutarate may occur in the rumen epithelium as well as the formation of glutamine from glutamate (Hoshino, Sarumaru \& Morimoto, I966). Fixation of ammonia $\mathrm{N}$ in rumen epithelium would protect the animal tissues from the toxic effects of ammonia and would enable the ruminant animal to control the rate of formation of blood urea from rumen ammonia. This would reduce the recycling of urea, a process which may waste energy through ureolysis and eventual synthesis of urea from the resultant ammonia. The fixation of ammonia $\mathrm{N}$ could also be important as an extrahepatic site for the synthesis of amino acids and could facilitate transport of rumen ammonia to other extrahepatic sites of amino acid synthesis. At high concentrations of rumen ammonia, the process of fixation in the rumen wall may become saturated so that a rise in portal blood ammonia would occur, as reported by Lewis et al. (I957).

Schoenheimer, Ratner \& Rittenberg (I939) obtained results with rats that indicated a rapid exchange of glutamic acid $\mathrm{N}$ with food and body amino acid $\mathrm{N}$. The retention of labelled $\mathrm{N}$ within the tissues of the sheep and to some degree the delay in excretion of ${ }^{15} \mathrm{~N}$ in the urine observed by us may not only indicate the extent of net utilization of ammonia, but could reflect exchange within the animal body as well. 


\section{Gaseous $N$ fixation}

Some $\mathrm{N}$ appeared to enter the rumen of the sheep given the barley ration, which was not accounted for by normal ways of entry (Table 6). It is fully recognized that this result was derived in only one trial and must be considered with reservation. However, errors of the order of 47 or $5 \mathrm{I} \%$ in the estimates of $\mathrm{N}$ outflow from rumen ammonia, or of outflow of $\mathrm{N}$ that was not converted into ammonia, respectively, would have been necessary to equalize inflow and outflow. It is possible that the difference arose from the fixation of gaseous $\mathrm{N}$ in the rumen, since the conditions of low rumen ammonia content and a highly fermentable substrate would be expected to favour such a process. If gaseous $\mathrm{N}$ was fixed in the rumen, this $\mathrm{N}$ may have been converted into rumen ammonia as shown, or it may have been fixed by the microbes without equilibration with extracellular ammonia, which, by our method of calculation, would cause us to underestimate the conversion of food $\mathrm{N}$ into ammonia in this sheep.

That fixation of $\mathrm{N}$ gas can occur in the rumen is indicated by the in vitro results of Hobson et al. (1968), who by using ${ }^{15} \mathrm{NH}_{4} \mathrm{Cl}$ showed that $7 \%$ of the $\mathrm{N}$ incorporated by the rumen micro-organism Bacteriodes amylophilus did not come from any source which could be determined by the Kjeldahl method.

The possible significance of fixation of $\mathrm{N}$ gas can be seen from calculations made by Kleiber (1956), which indicate that up to $7 \mathrm{~g}$ gaseous $\mathrm{N}$ could diffuse from the blood into the sheep rumen daily if the sheep rumen has one-tenth of the diffusion capacity of the bovine rumen. Hungate ( 1966 ) has suggested that under usual ruminal conditions there would be adequate fixed $\mathrm{N}$ for microbial growth, but under certain conditions there might be selection for a type of bacteria which would fix $\mathrm{N}$ gas.

Financial assistance provided for this research by the Alberta Agricultural Research Trust and the National Research Council of Canada is gratefully acknowledged. Sincere appreciation is extended to Dr A. J. F. Webster for excellent surgical preparations and to $\mathrm{Mr} \mathrm{D}$. G. Morgan for mass spectrometer analysis.

\section{REFERENCES}

Annison, E. F. \& Lewis, D. (1959). Metabolism in the Rumen p. I8. New York: John Wiley and Sons Inc. Badawy, A. M., Campbell, R. M., Cuthbertson, D. P., Fell, B. F. \& Mackie, W. S. (1958). Br. F. Nutr. 12, 367 .

Blackburn, T. H. (1965). In Physiology of Digestion in the Ruminant p. 322 [R. W. Dougherty, editor]. Washington: Butterworth Inc.

Blackburn, T. H. \& Hobson, P. N. (r960). Br. F. Nutr. 14, 445.

Bryant, M. P. \& Robinson, I. M. (I962). F. Bact. 84, 605.

Cocimano, M. R. \& Leng, R. A. (1967). Br. F. Nutr. 21, 353.

Conrad, H. R. \& Hibbs, J. W. (1968). F. Dairy Sci. 51, 276.

Cook, R. M., Brown, R. E. \& Davis, C. L. (1965). F. Dairy Sci. 48, 475.

Faust, H., Gürtler, H., Hübner, G., Hübner, H., Mielke, H., Rommel, W., Ulbrich, M. \& Wetzel, K. (1963). Arch. Tierernähr. 13, 475.

Faust, H., Mielke, H., Richter, H. \& Gürtler, H. (1966). Arch. Tierernähr. 16, 375.

Fawcett, J. K. \& Scott, J. D. (1960). F. clin. Path. 13, 156.

Ford, A. L. (r 969). Tracer studies of urea recycling and metabolism in the sheep. MSc Thesis, University of Alberta, Canada. 
Gray, F. V., Pilgrim, A. F. \& Weller, R. A. (1958). Br. J. Nutr. 12, 413.

Harris, L. E. \& Phillipson, A. T. (r962). Anim. Prod. 4, 97.

Hobson, P. N. (1965). F. gen. Microbiol. 38, 167.

Hobson, P. N., McDougall, E. I. \& Summers, R. (I968). F. gen. Microbiol. 5o, i.

Hobson, P. N. \& Summers, R. (I 967). F. gen. Microbiol. 47, 53.

Hogan, J. P. \& Phillipson, A. T. (1960). Br. F. Nutr. 14, 147.

Hogan, J. P. \& Weston, R. H. (1967a). Aust. F. agric. Res. 18, 803.

Hogan, J. P. \& Weston, R. H. (1967b). Aust. F. agric. Res. 18, 973.

Hogan, J. P. \& Weston, R. H. (1969). Aust. F. agric. Res. 20, 339.

Hoshino, S., Sarumaru, K. \& Morimoto, K. (1966). F. Dairy Sci. 49, I 523.

Houpt, T. R. (1959). Am. Y. Physiol. r97, Ir 5 .

Huhtanen, C. N. \& Gall, L. S. (I955). F. Bact. 69, 102.

Hungate, R. E. (1963). F. Bact. 86, 848 .

Hungate, R. E. (1966). The Rumen and its Microbes. New York: Academic Press Inc.

Kleiber, M. (1956). Publs natn. Res. Coun., Wash. no. 338, p. Io.

Land, H. \& Virtanen, A. I. (I959). Acta chem. scand. 13, 489.

Lewis, D., Hill, K. J. \& Annison, E. F. (1957). Biochem. F. 66, 587.

Meyer, J. H., Gaskill, R. L., Stoewsand, G. S. \& Weir, W. C. (I959). Y. Anim. Sci. 18, 336.

Mulligan, F. \& Workmall, A. (I959). Isotopic Tracers p. 402. London: The Athlone Press.

Norman, A. G. \& Jenkins, S. H. (1934). Biochem. I. 28, 2160.

Pilgrim, A. F., Gray, F. V. \& Belling, G. B. (1969). Br. F. Nutr. 23, 647.

Portugal, A. V. ( $\left.\mathrm{Ig}_{3}\right)$. Some aspects of protein and amino acid metabolism in the rumen of sheep. PhD Thesis, University of Aberdeen.

Roberts, R. B., Abelson, P. H., Cowie, D. B., Bolton, E. T. \& Britten, R. J. (1955). Publs Carnegie Instn no. 607, p. 13 .

Schoenheimer, R., Ratner, S. \& Rittenberg, D. (1939). F. biol. Chem. 130, 703.

Sheppard, C. W. (1962). Basic Principles of the Tracer Method. London: John Wiley and Sons Inc.

Smith, R. H. (1959). F. agric. Sci., Camb. 52, 72.

Smith, R. H., McAllan, A. B. \& Hill, W. B. (I968). Proc. Nutr. Soc. 27, 48 A.

Somers, M. (r96r). Aust. F. exp. Biol. med. Sci. 39, 145.

Steele, R., Wall, J. S., De Bodo, R. C. \& Altzuler, N. (1956). Am. F. Physiol. 187, 5.

Topps, J. H., Kay, R. N. B. \& Goodall, E. D. (1968). Br. F. Nutr. 22, 261.

Ulbrich, M. \& Scholz, H. (1963). Arch. Tierernähr. 13, 296.

Ulbrich, M. \& Scholz, H. (1966a). Arch. Tierernähr. 16, 325.

Ulbrich, M. \& Scholz, H. (1966b). Arch. Tierernähr. 16, 387.

Warner, A. C. I. (1956). Biochem. 7. 64, I.

Weller, R. A., Pilgrim, A. F. \& Gray, F. V. (1962). Br. F. Nutr. 16, 83.

Weston, R. H. \& Hogan, J. P. (1967). Aust. F. biol. Sci. 20, 967.

Weston, R. H. \& Hogan, J. P. (1968). Aust. F. agric. Res. 19, 567.

Note. After submission of this manuscript for publication, a report appeared by A. F. Pilgrim, F. V. Gray, R. A. Weller \& C. B. Belling [Br. F. Nutr. (1970), 24, 589] describing investigations similar to those in our experiments. Pilgrim et al. (1970) employed the technique of continuous intraruminal infusion of $\left({ }^{15} \mathrm{NH}_{4}\right)_{2} \mathrm{SO}_{4}$ as a means of labelling rumen ammonia. They measured absorption of rumen ammonia and estimated the extent of microbial incorporation of ammonia as the difference between the conversion of $\mathrm{N}$ into rumen ammonia and the rate of absorption. In contrast, we measured microbial yield and estimated absorption as the difference between the conversion of $\mathrm{N}$ into rumen ammonia and the quantity of ammonia $\mathrm{N}$ incorporated into microbes plus that ammonia $\mathrm{N}$ passing through the abomasum. Although our roughage diets consisted primarily of non-legume grass hays, whereas those of Pilgrim et al. (1970) were lucerne and wheaten hays, our results agree well with their values for $\mathrm{N}$ conversions in the rumens of sheep. They did not report results pertaining to turn-over times or utilization of absorbed ammonia. 